\title{
Fishers' perception of a 35-year old exclusive Fisheries Management Zone
}

\author{
Mark Dimech $^{\mathrm{a}, \mathrm{b}, \mathrm{d}, *}$, Michael Darmanin ${ }^{\mathrm{b}}$, I. Philip Smith ${ }^{\mathrm{c}}$, Michel J. Kaiser ${ }^{\mathrm{a}}$, Patrick J. Schembri ${ }^{\mathrm{d}}$ \\ a School of Ocean Sciences, University of Wales, Bangor, Menai Bridge, Anglesey LL59 5AB, United Kingdom \\ ${ }^{\mathrm{b}}$ Malta Centre for Fisheries Science (MCFS), Fort San Lucjan Marsaxlokk, BBG 1283, Malta \\ ${ }^{\mathrm{C}}$ University Marine Biological Station Millport, Isle of Cumbrae KA28 OEG, Scotland, United Kingdom \\ ${ }^{\mathrm{d}}$ Department of Biology, University of Malta, Msida MSD2080, Malta
}

\section{A R T I C L E I N F O}

\section{Article history:}

Received 19 September 2008

Received in revised form 14 May 2009

Accepted 19 June 2009

Available online 22 July 2009

\section{Keywords:}

Resource management

Attitudes

Management tools

Marine protected areas

\begin{abstract}
A B S T R A C T
Fishers' attitudes and perceptions are critical for the success of fisheries protection areas with their associated biota, and a failure to understand fishers' behaviour may undermine the success of such fisheries management measures. In this study, we examine fishers' perception of a long-established exclusive fisheries zone around Malta and to investigate if the perceptions depend on fishers' demographic, economic, social characteristics and fishing activity of the fishers. A questionnaire survey was undertaken to evaluate the demographic characteristics, economic situation (costs and revenue) and fishers' activity and behaviour, together with their perception of the Fisheries Management Zone (FMZ). A total of 241 interview responses were analysed which was a response rate of $60 \%$. The perception of most fishers was that the establishment of the FMZ has had an overall negative impact on their fishing activity and that the zone is not important for the protection of local fish stocks. When asked about the beneficial effect of the zone for fishers, most fishers from all backgrounds said that the zone does not benefit commercial fishers, but benefits mainly recreational fishers. The most evident differences in the perceptions and attitudes were between the full-time, part-time and recreational fishers. Fishers that have been fishing for more than 35 years and fishers from the main fishing village also had different attitudes from other fishers towards the FMZ. The results of this study suggest that the proportion of individual income derived from fishing was the strongest factor that influenced attitudinal differences, with home port and fishing experience having less important effects. The main differences in attitude among fishers were related to the protection and conservation effects of the zone, enhancement of resources and conflicts among user groups. The heterogeneity among fishers' attitudes revealed by the present study has important implications for the implementation of spatial closures. Some sectors of stakeholders may require additional incentives to accept restrictions on access if spatial management is to achieve its intended objectives.
\end{abstract}

(c) 2009 Elsevier Ltd. All rights reserved.

\section{Introduction}

The design of institutions for both aquatic and terrestrial resource management should take into account the characteristics of the individual resource systems and the relevant users as these will critically affect success (Runolfsson, 1997; Fortmann, 1990, 1995; McHenry, 1996; Moore, 1994). These principals apply equally to examples ranging from marine fish, bush meat or harvested freshwater resources (Gelcich et al., 2006; Redford, 1987; Jones et al., 2006). The effectiveness of management will be severely compromised if users do not comply with such institutions (for example Hanna and Smith, 1993; Kaplan, 1998). Even if users comply with the letter of the law, there may be unintended consequences of their efforts to maintain their income under restrictive

\footnotetext{
* Corresponding author. Address: Malta Centre for Fisheries Science (MCFS), Fort San Lucjan Marsaxlokk, BBG 1283, Malta. Tel.: +356 22293302.

E-mail address: mark.dimech@gov.mt (M. Dimech).
}

regulations. Consequently, there is an urgent need to understand fishers' attitudes and the influences that act upon them, as this may further our understanding of current behaviour and will help to predict likely responses to new management strategies (Kaiser, 2005).

The sustainable use of natural resources in the marine environment is of paramount importance given current rates of global population growth. At present, wild capture marine fisheries annually provide c.85 Mt of protein compared with c. $245 \mathrm{Mt}$ of protein (excluding milk) produced from terrestrial agricultural systems. The chronic failure of management institutions has led to well documented global declines in many fisheries (Pauly et al., 2002; Myers and Worm, 2003). In this context, there is greater interest in and application of spatially explicit restrictions of fishing effort through the use of marine reserves or temporal closures (Agardy et al., 2003; Gell and Roberts, 2003). The success of such measures depends on the extent to which fishers are willing to comply with such systems (Jentoft and McCay, 1995; Jentoft et al., 1998; 
Zanetell and Knuth, 2004; Richardson et al., 2005). The failure to understand and manage fishers' behaviour has contributed to many fisheries problems (Hilborn, 1985; Jentoft et al., 1998).

If the management of wild-harvest resources is to succeed, it is necessary to understand the perceptions and attitudes of fishers so as to be able to predict their likely response to current and new policy or management measures (McManus, 1996; Hanna, 2001). At present, the major insights to fishers' behaviour have arisen from standard economic and common property theory, which suggest that if fishers engage in rational economic behaviour, then the overexploitation of open-access resources is inevitable (Gordon, 1954; Hardin, 1968). An underlying assumption of these theories is that all fishers are motivated by the same desire for financial gain and engage in similar decision-making processes (Hanna and Smith, 1993), although research shows that they are generally more heterogeneous in their motivation and behaviour than previously assumed (Hanna and Smith, 1993; Jentoft and Davis, 1993; Gelcich et al., 2005a; Richardson et al., 2005).

For individuals, the interaction between their attitudes and objectives that influence behaviour is reflected in the theory of reasoned action (Fishbein and Ajzen, 1975; Ajzen, 1988), which underpins much social and psychological work undertaken in recent years. This theory suggests that behaviour is best predicted by the intentions of individuals within a population, which in turn are affected by the members' attitudes and the influences of significant others on their intentions to act. The person's attitude, combined with subjective norms, forms one's "behaviour intention" (Fishbein and Ajzen, 1975; Ajzen, 1991). Alternative models, such as the transactional model of behaviour, propose that attitudes can also influence behaviour directly, and that these attitudes are affected by psychological and environmental variables (Bentler and Speckart, 1979; Lazarus and Folkman, 1984). These theories have been applied to the economic behaviour of a range of natural resource-users, and results suggest that personal and business characteristics significantly affect the attitudes and economic behaviours of farmers and fishers (Featherstone and Goodwin, 1993; Filson, 1993; Traoré et al., 1998; Willock et al., 1999a,b; Austin et al., 2001; Jacobson et al., 2003). Specific studies on fishers indicate that their behaviour can be influenced by a combination of factors, including their attitudes (for example, regarding the legitimacy of the regulatory process), a social component (including moral values and peer pressure) and various demographic variables (Jentoft and Davis, 1993; Hart, 1998; Hatcher et al., 2000; Blyth et al., 2002; Eggert and Ellegård, 2003; Flaaten and Heen, 2005; Richardson et al., 2005).

Property rights may also be a major determinant of fishers' attitudes and behaviour (Hardin, 1968; Blyth et al., 2002; Dalton et al., 2004; Hannesson, 2004; Janmaat, 2005). Individuals respond to economic incentives, which in turn are influenced by the prevailing property rights structure (Furubotn and Pejovich, 1972). Weak or absent property rights can create incentives for overexploitation and consequent resource depletion, while stronger rights, whether formally or informally granted, can incentivize resource conservation and stewardship as future returns are subject to protection (De Alessi, 1998; Dalton et al., 2004). Research suggests that incentives for resource stewardship are influenced by factors such as the resource characteristics, resource-user group characteristics, institutional arrangements and history (Wade, 1988; Ostrom, 1990; Baland and Platteau, 1996; Agrawal, 2001; Hanna, 2001). Interestingly, in a study of a trawl fishery, Hanna and Smith (1993) found that many of their respondents had long-term plans and a vested interest in resource sustainability and conservation, while fishers' perceptions of management and problems associated with over-fishing varied among ports and age-groups. Similarly, Jentoft and Davis (1993) identified two distinct attitudinal approaches to fishing among small-boat fishers in Nova Scotia, which reflected fishers' ages, education and experiences. Other studies also suggest that attitudes to management vary among groups of fishers with different previous experiences of management (Gelcich et al., 2005a,b), or among groups using different types of fishing gears (Blyth et al., 2002). Richardson et al. (2005) concluded that fishers' attitudes are related to the fishery characteristics of the sector and its resource base: in particular, target species' mobility and past sector experiences predicted the inclination of fishers in each sector towards resource stewardship.

Since 1971, Malta has managed fishing in a zone surrounding the Maltese archipelago extending to 25 nautical miles (NM) from baselines and covering an area of $11,980 \mathrm{~km}^{2}$ (Fig. 1). The objective of the original Exclusive Fishing Zone (EFZ) was to protect local artisanal fisheries by excluding foreign large-scale commercial fishing, especially trawling. After Malta became a member of the European Union (EU) in 2004, fishing in its waters became subject to the Common Fisheries Policy and fishing vessels from other EU member states gained access to Malta's waters beyond 12 nautical miles. However, in the interests of fishery conservation, the 25-NM zone was retained as a Fisheries Management Zone (FMZ) with limitations on fishing effort, vessel sizes and spatial restrictions on certain types of fishing activity. Until recently, the fishing regulations in force in the EFZ were those published in 1934 (Fish Industry Act), with minor changes over the years (Camilleri, 2005). These regulations included a ban on trawling within territorial waters (which at the time extended to 3 nautical miles; the restriction was maintained within 3 nautical miles even after the extension of Maltese territorial waters to 12 nautical miles in 1971). Prior to Malta's accession to the EU, a new management regime was proposed (Camilleri, 2003), agreed and later implemented after accession through Council Regulation EC 813/2004, which, inter alia, restricted trawling to specified areas based on the trawlable grounds identified during a survey in 1978 made in collaboration with the Food and Agriculture Organization (FAO) (Giudicelli, 1978).

The present study examined the perceptions of resources users towards a long-term management strategy (the Maltese Fisheries Management Zone) that was designed to protect long-term sustainability of the fisheries on which they depended. The study set out to examine differences in attitude and perception towards the FMZ among different sectors of the resource-user community. We explored potential differences in attitude in relation to demographic, economic and social characteristics.

\section{Methodology}

The fisheries in the Maltese archipelago constitute a relatively small industry, the social significance of which far outweighs its economic importance. Much of the fishing activity is based on traditional methods (except trawling) and operates on a small scale, producing small volumes of high-value products. The industry is mainly artisanal and fairly typical of the fisheries found in many Mediterranean countries (Leiva et al., 1998). Approximately $1 \%$ of the working population is dependent (to varying extents) on fishing for its livelihood. All vessels used for fishing are required by law (Malta Fishing Vessels Regulations L.425.07, 2004) to be licensed and registered in the Fishing Vessels Register (FVR). The FVR is divided into three main categories as follows: MFA (full-time commercial fishing vessels), MFB (part-time commercial fishing vessels) and MFC (non-commercial, i.e. recreational, fishing vessels). The term "full-time" is applied to fishers whose main income is derived entirely from fishing. It should be noted that fishing in Malta is mainly seasonal and consequently some of the full-time fishers own at least one small and one large vessel, which enables them to practice off-shore fishing during the calmer seasons 


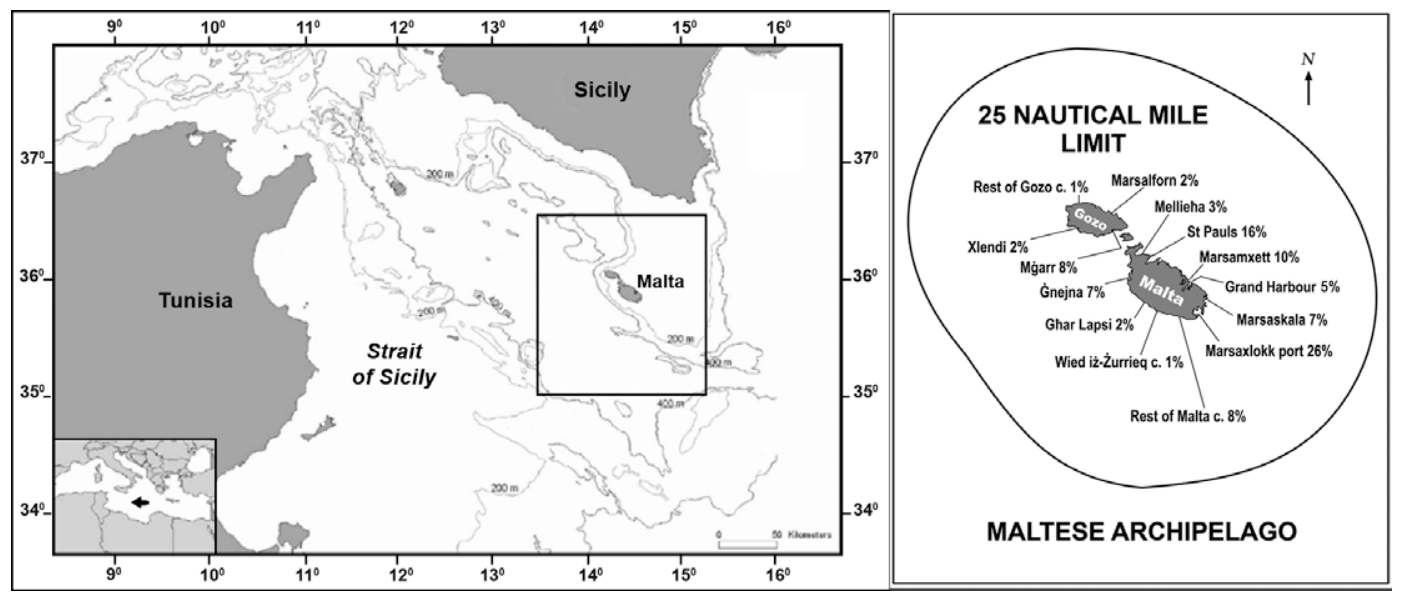

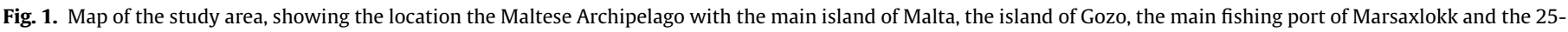
NM limit. The figure also shows the percentage distribution of fishers in each fishing port.

(April-September) and coastal or inshore activities during the winter months. Approximately $26 \%$ of the fishing vessels in the Maltese archipelago are based in the fishing village of Marsaxlokk, while $16 \%$ are based on the island of Gozo. The rest are based in many different ports around the islands (Fig. 1), with a homogenous fishing activity. The only area with a relatively higher fishing intensity is near the port of Marsaxlokk (Stelzenmüller et al., 2008).

\subsection{Sampling design}

The attitudes and perceptions of full-time (MFA), part-time (MFB) and recreational (MFC) fishers were investigated using a questionnaire survey. Fishers to be sampled were selected according to information recorded in MALTASTAT, a reliable and efficient computerized fisheries statistics system, which includes a register/ inventory of fishing vessels. The Maltese fishing fleet consists of 2252 vessels, of which there are 178 vessels of $>10 \mathrm{~m}$ L.O.A. ( $8 \%$ of the fleet). Sampling was stratified by vessel length. It was planned to survey all skippers (masters) of vessels in $>10 \mathrm{~m}$ and the skippers of a random sample comprising $10 \%$ of the vessels $<10 \mathrm{~m}$. This yielded a total sample size of 400 , constituting $17.8 \%$ of the fleet. Although it is possible, in principle, for vessels from other EU member states to fish in the FMZ, in practice no foreign vessels have a licence to fish in this area.

A questionnaire was designed to evaluate the demographic characteristics, economic circumstances (costs and revenue) and activity of fishers, together with their perceptions of the Maltese 25-NM FMZ. The selected skippers were surveyed by means of telephone interview in January/February 2006. In the previous September, a letter was sent to the Maltese Fisheries Board and to the fisheries cooperatives to inform them that members of their organization may be asked to participate in a fisheries survey. A letter was also sent to each of the selected registered fishers, giving them details about the survey and why it was being conducted, and that they were selected as interviewees. They were asked for full coop- eration and in turn it was stated that the survey would be kept as simple as possible, so as not to take up too much of their time. Technical data on the fleet, such as vessel length, weight and power, and demographic data on vessel owners were obtained from the Malta fleet vessel register. A total of 241 interviews were conducted, equating to an overall response rate of $60.3 \%$ (Table 1 ).

For questions regarding those factors that influence the choice of fishing site, a rank system was used in which a choice of 10 predetermined factors which could influence the choice of fishing site (Table 2), were listed with an additional free-text response. The interviewees were asked to rank the five most important factors influencing their choice of fishing site (with rank 1 being the most important).

Questions about perceptions of the FMZ and fishing strategies were based on a five-point Likert-scale (with anchor points ranging from 'strongly agree' to 'strongly disagree'), while questions on the relationships with other users of the FMZ were based on a threepoint Likert-scale (with anchor points corresponding to 'cooperation', 'no contact' and 'conflict'). Interview transcripts were entered into a Microsoft Access database.

\subsection{Data analysis}

For analysis, the fleet was categorised in two main ways. The first was based on the type of licence category (i.e. MFA, MFB, MFC), which reflects the livelihood dependence on fishing, with MFA licence holders deriving their entire income from fishing, MFB licence holders use fishing to supplement income from their main job, while MFC licence holders do not depend economically on fishing at all, since for them fishing is only a leisure activity.

The second classification was based on the predominant fishing gear utilised by each fisher as determined by the percentage of trips in which a particular gear was used (determined from the species landed). This is especially important in countries in which fishers use more than one type of gear. Vessels that used only one type of gear were categorised as an exclusive fishing vessel (e.g.

Table 1

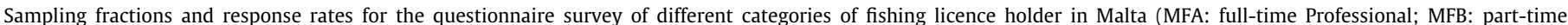
Professional; MFC: recreational).

\begin{tabular}{|c|c|c|c|c|}
\hline Licence category & Total no. vessels & Target sample (\% of fleet) & Vessels sampled (\% of fleet) & Response rate (\%) \\
\hline MFA & 432 & $161(37.3)$ & $122(28.2)$ & 75.8 \\
\hline MFB & 993 & $137(13.8)$ & $72(7.3)$ & 52.6 \\
\hline MFC & 826 & $102(12.3)$ & $47(5.7)$ & 46.1 \\
\hline Total & 2251 & $400(17.8)$ & $241(10.7)$ & 60.3 \\
\hline
\end{tabular}


Table 2

Predetermined factors asked which could influencing the choice of fishing site.

\begin{tabular}{lll}
\hline $\begin{array}{l}\text { Regulations } \\
\text { Abundance of fish }\end{array}$ & Distance to port & Equipment \\
$\begin{array}{l}\text { Weather } \\
\text { To go where other fishermen went }\end{array}$ & Particular species \\
Crew availability & Engine power \\
\hline
\end{tabular}

'exclusive trawler'), while vessels that used a particular gear $50 \%$ or more of the time spent fishing were categorised as a non-exclusive vessel (e.g. 'non-exclusive netter').

Apart from the two main categories, differences in attitudes and perceptions were also explored for other a priori designated categories. The other classifications used included home port sub-divided into three categories (the second largest island of the archipelago, Gozo, the main fishing village Marsaxlokk, and the other small fishing villages grouped together); years of fishing experience ( $>35 \mathrm{y}, 15-35 \mathrm{y}$ and $<15 \mathrm{y}$ ); vessel size ( $>24 \mathrm{~m}, 12-24$ $\mathrm{m}$ and $<12 \mathrm{~m}$ L.O.A).

The fishers' responses based on the five- and three-point Likertscales were converted to numerical scores from 5 (fully agree) to 1 (completely disagree) and 3 (cooperation) to 1 (conflict) for the fishers' perceptions and relations, respectively.

Differences among licence and gear categories in the demographic and economic characteristics of the fleet were tested with one-way analysis of variance (ANOVA) followed by the Tukey pairwise multiple comparison test. When the assumptions of ANOVA were not met, the Kruskal-Wallis test was applied, followed by the modified Dunnet pairwise multiple comparison test. When variables for only two groups were available the Mann-Withney test was used. A Bonferroni adjustment for the number of tests made within each classification was applied to counter the effects of multiple testing (Type I errors).

To test for significant positive or negative deviations from the neutral score, the numerical scores were tested using the nonparametric Wilcoxon signed rank test for each question for each category analysed.

For each respondent there were 32 dependent variables (16 Likert-scale scores and 16 coded scores) that provided a semi-quantitative representation of each individual's views on the issues discussed during the interview. These non-parametric multivariate data were analysed using PRIMER (Clarke and Warwick, 1994) to investigate how the whole suite of attitudes expressed varied within and among the five categories of fishers. A similarity matrix was constructed using the Bray-Curtis index of similarity. A oneway analysis of similarity randomized permutation test (ANOSIM) was used to investigate whether significant differences existed among the different categories of fishers identified a priori. The similarity percentages routine (SIMPER) was used to identify the attitudes that contributed most to any differences that occurred between the fishers' categories and ordination plots were created (using non-metric multi-dimensional scaling) to allow visual comparison of respondents' responses. We examined whether demographic variables pertaining to individual fishers could explain patterns in the attitudinal data using the BIOENV routine. This procedure calculated the rank correlation between similarity matrices constructed for the variables and the attitudinal data.

\section{Results}

\subsection{General characteristics of fisher categories}

The main fishing sectors identified used different types of gear throughout the year, except for bottom otter trawlers, that used this gear exclusively. The largest category of fishers were the non-exclusive seine netters that used fish aggregating devices to attract, dolphinfish (Coryphaena hippurus). This type of fishing was carried out from 15th August until the end of December. At other times of year, these fishers practiced either coastal fishing or surface longlining during the tuna season. The non-exclusive netters used trammel nets, gill nets and combined trammel-gill nets throughout the year, but also fished for dolphinfish during the peak of the dolphinfish season. The other category identified was the non-exclusive longliners, which practiced longlining throughout the year. During the bluefin tuna (Thunnus thynnus) and swordfish (Xiphias gladius) season they used drifting surface longlines and for the rest of the year they fished with bottom longlines. The fishers of this group also fished for dolphinfish during the peak of the season.

The remaining group identified was recreational fishers, who mostly used rod and line, hand line, and trolling lines to fish for a variety of demersal and pelagic species, mostly in coastal waters within 3 nautical miles of the coastline. The recreational fishers were also grouped by type of fishing licence (MFC).

As expected, recreational fishers differed significantly $(P<0.05)$ from professional fishers (especially full-time professionals) in most respects, being older, less-experienced, having smaller, less

Table 3

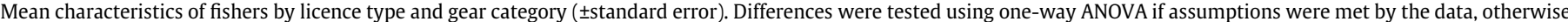

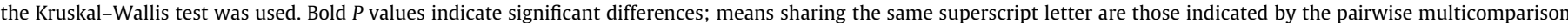

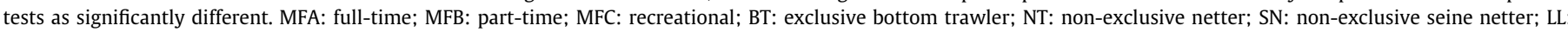
non-exclusive longliner.

\begin{tabular}{|c|c|c|c|c|c|c|c|}
\hline \multirow{3}{*}{$\begin{array}{l}\text { Characteristic } \\
\text { Age (y) }\end{array}$} & \multicolumn{7}{|l|}{ Licence type } \\
\hline & \multirow{2}{*}{$\frac{\text { MFA }}{45^{\mathrm{a}}(13)}$} & \multirow{2}{*}{$\frac{\text { MFB }}{48(12)}$} & \multirow{2}{*}{$\frac{\text { MFC }}{51^{\mathrm{a}}(13)}$} & \multirow{2}{*}{$\begin{array}{l}\text { All } \\
47(13)\end{array}$} & \multicolumn{2}{|c|}{ Test statistic } & \multirow{2}{*}{$\frac{P}{0.03}$} \\
\hline & & & & & $\mathrm{F}$ & 3.5 & \\
\hline Time fishing (y) & $24^{\mathrm{a}}(14)$ & $21^{\mathrm{b}}(14)$ & $13^{\mathrm{a}, \mathrm{b}}(12)$ & $21(14)$ & $\mathrm{F}$ & 11.8 & $<0.01$ \\
\hline Vessel length (m) & $14.2(5.9)^{\mathrm{a}}$ & $7.0(2.7)^{\mathrm{a}}$ & $5.5(1.7)^{\mathrm{a}}$ & $10.4(6)$ & $\chi^{2}$ & 126.0 & $<0.01$ \\
\hline Gross tonnage & $29.5(46.1)^{\mathrm{a}}$ & $3.7(6.2)^{\mathrm{a}}$ & $1.5(1.7)^{\mathrm{a}}$ & $16.1(35.3)$ & $\chi^{2}$ & 123.6 & $<0.01$ \\
\hline Engine power (kW) & $182.2(144.5)^{\mathrm{a}}$ & $58.7(56.4)^{\mathrm{a}}$ & $33.5(41.8)^{\mathrm{a}}$ & $115.7(127.6)$ & $\chi^{2}$ & 99.8 & $<0.01$ \\
\hline Year of construction & $1976(35)$ & $1984(18)$ & 1985 (19) & $1980(28)$ & $\mathrm{F}$ & 2.9 & 0.06 \\
\hline Usual crew size & $4(2)^{a b}$ & $3(1)^{a}$ & $2(1)^{\mathrm{b}}$ & $3(2)$ & $\chi^{2}$ & 72.6 & $<0.01$ \\
\hline Distance to fishing grounds ( $\mathrm{km})$ & $74.5(50.6)^{\mathrm{a}}$ & $23.0(28.9)^{\mathrm{a}}$ & $9.7(17.3)^{\mathrm{a}}$ & $41.9(47.3)$ & $\chi^{2}$ & 89.3 & $<0.01$ \\
\hline Annual number of trips at sea & $64(61)^{\mathrm{ab}}$ & $36(42)^{a}$ & $32(42)^{b}$ & $45(52)$ & $\chi^{2}$ & 14.3 & $<0.01$ \\
\hline$\%$ of trips within the FMZ & $51(41)^{\mathrm{a}}$ & $82(30) a$ & $100(0) a$ & $81(33)$ & $\chi^{2}$ & 42.8 & $<0.01$ \\
\hline Trip duration (d) & $5.0(4.5)^{\mathrm{a}}$ & $1.6(1.1)^{\mathrm{a}}$ & $1.0(0)^{\mathrm{a}}$ & $3.0(3.6)$ & $\chi^{2}$ & 102.3 & $<0.01$ \\
\hline Second-hand value of vessel and gears (Euro) & $149400(199208)$ & $13741(10770)$ & $\mathrm{N} / \mathrm{A}$ & $110640(179056)$ & $\mathrm{Z}$ & -6.6 & $<0.01$ \\
\hline Annual costs of running the vessel (Euro) & $6868(16156)^{a}$ & $2425(3994)^{\mathrm{b}}$ & $792(1360)^{\mathrm{ab}}$ & $3998(11182)$ & $\chi^{2}$ & 19.2 & $<0.01$ \\
\hline Annual total landings ( $\mathrm{kg}$ ) & $5338(7326)^{\mathrm{ab}}$ & $601(1465)^{\mathrm{a}}$ & $13(22)^{b}$ & $3588(6382)$ & $\chi^{2}$ & 19.3 & $<0.01$ \\
\hline Annual value of landings (Euro) & 24120 (33199) & $2181(4482)$ & $\mathrm{N} / \mathrm{A}$ & $18854(30475)$ & $\mathrm{Z}$ & -4.7 & $<0.01$ \\
\hline
\end{tabular}


powerful, vessels, fewer 'crew', making only day trips and therefore fishing closer to port (and entirely within the FMZ), incurring lower costs and landing much smaller quantities of catch (Tables 3 and 4 ). The number of fishing trips per year made by recreational fishers did not differ significantly from part-time professionals, but was significantly less than full-time fishers.

With respect to the classification by licence category for the professional fishers (MFA and MFB) the type of fishery and hence the gear used did not depend on the type of licence. Nevertheless, some differences between these two groups were still detected (Tables 3 and 4). Part-time fishers used smaller, less powerful, less valuable vessels with fewer crew than full-time fishers. Although part-time fishers did not make significantly fewer trips per year, their trips were considerably shorter in duration and distance, have lower running costs and produce landings of around 10\% that of full-time fishers by weight and value. Part-time fishers (MFB) fished mostly inside the FMZ, whereas around half of the trips undertaken by full-time fishers extend beyond the FMZ.

\subsection{Choice of fishing site}

All groups gave 'regulations' as the first or second most important factor influencing their choice of locations where they chose to fish, except for recreational fishers (MFC), who indicated that their choice was more closely related to accessibility to the fishing site, abundance of fish and weather (Table 5). The next two important decision criteria for professional fishers were abundance of fish and weather so this may mean that fishers will change their fishing activity and fishing grounds according to the state of the resource. If a resource is depleted they will move onto the site were fish are the most abundant

\subsection{Fishers' perceptions}

In general the different classifications of fishers had similar perceptions of the effectiveness of the FMZ in some aspects, but there were some differences among groups (Fig. 2). The perceptions of

Table 4

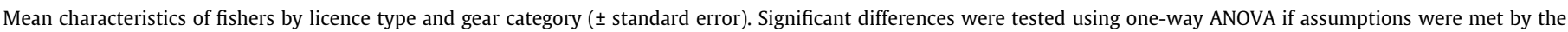

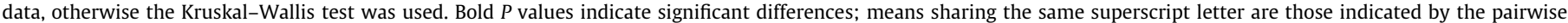
multicomparison tests as significantly different. BT: exclusive bottom trawler; NT: non-exclusive netter; SN: non-exclusive seine netter; LL: non-exclusive longliner.

\begin{tabular}{|c|c|c|c|c|c|c|c|c|}
\hline \multirow{3}{*}{$\begin{array}{l}\text { Characteristic } \\
\text { Age }\end{array}$} & \multicolumn{8}{|l|}{ Gear category } \\
\hline & \multirow{2}{*}{$\begin{array}{l}\text { BT } \\
46.0(11)\end{array}$} & \multirow{2}{*}{$\frac{\mathrm{NT}}{48(14)}$} & \multirow{2}{*}{$\frac{\mathrm{SN}}{48(12)}$} & \multirow{2}{*}{$\frac{\mathrm{LL}}{43^{\mathrm{a}}(13)}$} & \multirow{2}{*}{$\frac{\text { MFC }}{51^{\mathrm{a}}(13)}$} & \multicolumn{2}{|c|}{ Test statistic } & \multirow{2}{*}{$\frac{P}{0.03}$} \\
\hline & & & & & & $\mathrm{F}$ & 2.7 & \\
\hline Time fishing $(y)$ & $20(14)$ & $22(15)$ & $24^{\mathrm{a}}(14)$ & $22^{\mathrm{b}}(15)$ & $13^{\mathrm{a}, \mathrm{b}}(12)$ & $\mathrm{F}$ & 5.6 & $<0.01$ \\
\hline Boat length (m) & $24.6(6)^{\text {abcde }}$ & $6.4(1.9) \mathrm{b}$ & $10.4(4.8)^{\mathrm{c}}$ & $11.7(5.3)^{d}$ & $5.5(1.7) \mathrm{e}$ & $\chi^{2}$ & 85.9 & $<0.01$ \\
\hline Gross tonnage & $126.2(91.1)$ & $1.9(1.5)$ & $11.8(14.4)$ & $15.4(18.5)$ & $1.5(1.7)$ & $\chi^{2}$ & 97.3 & $<0.01$ \\
\hline Power $(\mathrm{kW})$ & $416.3(217.5)$ & $48.4(39.2)$ & $121.3(106.8)$ & $124.0(100.7)$ & $33.5(41.8)$ & $\chi^{2}$ & 72.0 & $<0.01$ \\
\hline Year of construction & $1986(13)$ & $1977(28)$ & $1979(37)$ & $1978(22)$ & 1985 (19) & $\tilde{F}$ & 0.6 & 0.67 \\
\hline Usual crew size & $5(2)^{\mathrm{ab}}$ & $2(1)^{\text {ace }}$ & $4(2)^{\mathrm{cd}}$ & $4(1)^{\text {ef }}$ & $2(1)^{\text {bdf }}$ & $\chi^{2}$ & 42.9 & $<0.01$ \\
\hline Distance to fishing grounds (km) & $77.1(41.1)^{\mathrm{a}}$ & $44.7(49.3)$ & $54.8(56.0)^{\mathrm{b}}$ & $41.9(37.9)^{\mathrm{c}}$ & $9.7(17.3)^{\mathrm{abc}}$ & $\chi^{2}$ & 50.7 & $<0.01$ \\
\hline Annual number of trips at sea & $68(26)$ & $36(42)$ & $47(54)$ & $54(58)$ & $32(42)$ & F & 1.1 & 0.35 \\
\hline$\%$ of trips at sea inside the FMZ & $65.0(49.5)$ & $79.0(30.0)$ & $65.2(40.9)^{\mathrm{a}}$ & $75.8(33.8)^{b}$ & $100(0)^{\mathrm{ab}}$ & $\chi^{2}$ & 30.8 & $<0.01$ \\
\hline Trip duration $(\mathrm{d})$ & $3.2(1.5)$ & $1.8(1.3)$ & $4.1(3.8)$ & $3.7(4.5)$ & $1.0(0)$ & $\tilde{F}$ & 0.9 & 0.43 \\
\hline Second-hand value of boat and gears (Euro) & $517678(279724)^{\mathrm{abc}}$ & $9918(49230)^{\text {aef }}$ & $85794(158009)^{\text {be }}$ & $84849(78514)^{\mathrm{cf}}$ & $\mathrm{N} / \mathrm{A}$ & $\chi^{2}$ & 22.5 & $<0.01$ \\
\hline Annual costs of running the vessel (Euro) & $3860(6911)$ & $3141(6900)$ & $6777(16862)^{\mathrm{a}}$ & $2912(4157)^{\mathrm{b}}$ & $792(1360)^{\mathrm{ab}}$ & $\chi^{2}$ & 19.9 & $<0.01$ \\
\hline Annual total landings (kg) & $9011(9281)$ & $10872(9411)$ & $3457(6333)^{\mathrm{a}}$ & $3478(5848)^{\mathrm{b}}$ & $13(22)^{\mathrm{ab}}$ & $\tilde{\chi}^{2}$ & 14.3 & $<0.01$ \\
\hline Annual value of landings (Euro) & 42188 (34639) & $12487(15932)$ & $20014(31491)$ & $14321(28423)$ & $\mathrm{N} / \mathrm{A}$ & $\mathrm{F}$ & 2.1 & 0.11 \\
\hline
\end{tabular}

Table 5

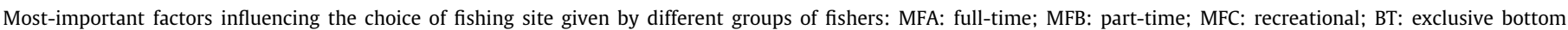
trawler; NT: non-exclusive netter; SN: non-exclusive seine netter; LL: non-exclusive longliner.

\begin{tabular}{|c|c|c|c|c|c|c|}
\hline \multirow[t]{3}{*}{ Classification } & \multirow[t]{3}{*}{ Category } & \multicolumn{5}{|c|}{ Factor affecting choice of fishing site } \\
\hline & & \multicolumn{4}{|l|}{ Most important } & \multirow{2}{*}{$\begin{array}{l}\text { Least important } \\
5\end{array}$} \\
\hline & & 1 & 2 & 3 & 4 & \\
\hline Gear category & $\begin{array}{l}\text { Exclusive bottom trawler } \\
\text { Non-exclusive netter } \\
\text { Non-exclusive seiner } \\
\text { Longliner }\end{array}$ & $\begin{array}{l}\text { Abundance of fish } \\
\text { Experience } \\
\text { Regulations } \\
\text { Regulations }\end{array}$ & $\begin{array}{l}\text { Regulations } \\
\text { Regulations } \\
\text { Weather } \\
\text { Weather }\end{array}$ & $\begin{array}{l}\text { Weather } \\
\text { Abundance of fish } \\
\text { Experience } \\
\text { Experience }\end{array}$ & $\begin{array}{l}\text { Distance to port } \\
\text { Weather } \\
\text { Abundance of fish } \\
\text { Abundance of fish }\end{array}$ & $\begin{array}{l}\text { Experience } \\
\text { Distance to port } \\
\text { Distance to port } \\
\text { Equipment }\end{array}$ \\
\hline Licence category & $\begin{array}{l}\text { MFA } \\
\text { MFB } \\
\text { MFC }\end{array}$ & $\begin{array}{l}\text { Regulations } \\
\text { Experience } \\
\text { Accessibility }\end{array}$ & $\begin{array}{l}\text { Experience } \\
\text { Regulations } \\
\text { Abundance of fish }\end{array}$ & $\begin{array}{l}\text { Abundance of fish } \\
\text { Abundance of fish } \\
\text { Weather }\end{array}$ & $\begin{array}{l}\text { Experience } \\
\text { Weather } \\
\text { Experience }\end{array}$ & $\begin{array}{l}\text { Distance to port } \\
\text { Distance to port } \\
\text { Regulations }\end{array}$ \\
\hline Time fishing & $\begin{array}{l}<15 y \\
15-35 y \\
>35 y\end{array}$ & $\begin{array}{l}\text { Regulations } \\
\text { Regulations } \\
\text { Regulations }\end{array}$ & $\begin{array}{l}\text { Experience } \\
\text { Abundance of fish } \\
\text { Weather }\end{array}$ & $\begin{array}{l}\text { Abundance of fish } \\
\text { Weather } \\
\text { Experience }\end{array}$ & $\begin{array}{l}\text { Weather } \\
\text { Experience } \\
\text { Abundance of fish }\end{array}$ & $\begin{array}{l}\text { Accessibility } \\
\text { Distance to port } \\
\text { Season }\end{array}$ \\
\hline Base port & $\begin{array}{l}\text { Other } \\
\text { Marsaxlokk } \\
\text { Gozo }\end{array}$ & $\begin{array}{l}\text { Regulations } \\
\text { Regulations } \\
\text { Regulations }\end{array}$ & $\begin{array}{l}\text { Experience } \\
\text { Weather } \\
\text { Abundance of fish }\end{array}$ & $\begin{array}{l}\text { Weather } \\
\text { Abundance of fish } \\
\text { Experience }\end{array}$ & $\begin{array}{l}\text { Abundance of fish } \\
\text { Experience } \\
\text { Distance to port }\end{array}$ & $\begin{array}{l}\text { Accessibility } \\
\text { Season } \\
\text { Weather }\end{array}$ \\
\hline Vessel size & $\begin{array}{l}<12 \mathrm{~m} \\
12-24 \mathrm{~m} \\
>24 \mathrm{~m}\end{array}$ & $\begin{array}{l}\text { Experience } \\
\text { Regulations } \\
\text { Regulations }\end{array}$ & $\begin{array}{l}\text { Regulations } \\
\text { Abundance of fish } \\
\text { Abundance of fish }\end{array}$ & $\begin{array}{l}\text { Weather } \\
\text { Weather } \\
\text { Weather }\end{array}$ & $\begin{array}{l}\text { Abundance of fish } \\
\text { Experience } \\
\text { Distance to port }\end{array}$ & $\begin{array}{l}\text { Accessibility } \\
\text { Go were other fishers go } \\
\text { Go were other fishers go }\end{array}$ \\
\hline Overall & & Regulations & Abundance of fish & Weather & Experience & Distance to port \\
\hline
\end{tabular}




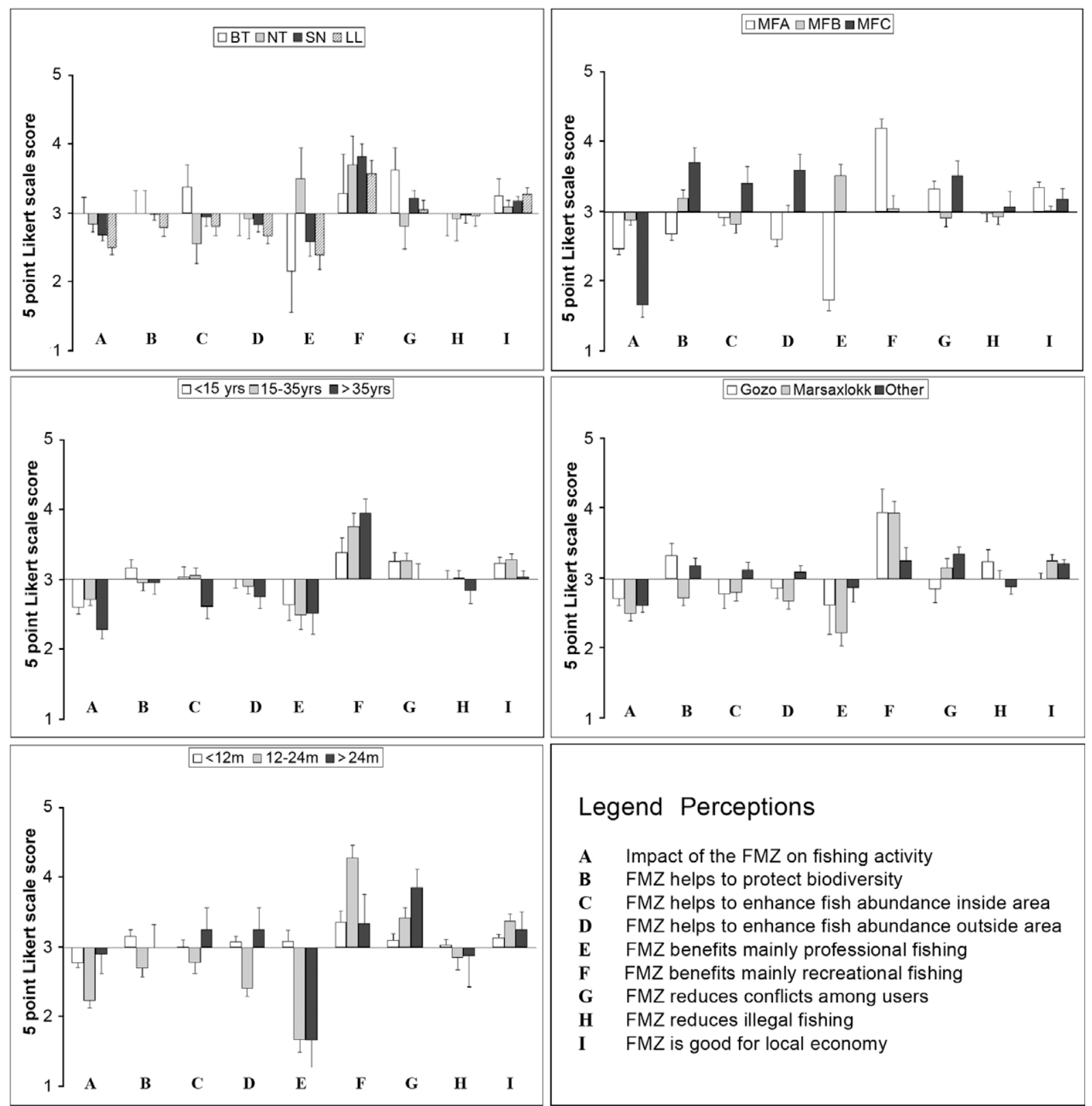

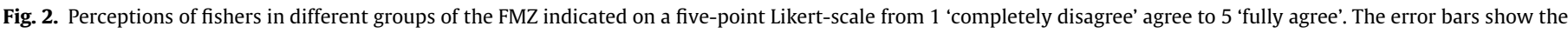

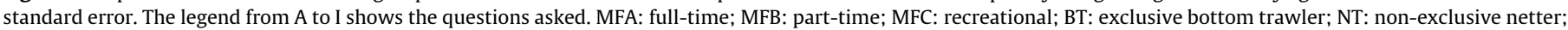
$\mathrm{SN}$ : non-exclusive seine netter; LL: non-exclusive longliner.

trawlers and netters sometimes deviated from the neutral response (score 3), but these were not significant deviations, which implied that the fishers do not think that the FMZ has an impact in relation to the questions posed to them (Table 6).

Most of the fishers in each of the different categories thought that the establishment of the FMZ has had a negative impact overall on their fishing activity. Significant results $(P<0.05$; Table 6$)$ were obtained for seine netters, longliners, full-time, recreational, experienced and inexperienced fishers, all home ports (except Gozo) and all of the vessel length classes (except vessels $>24 \mathrm{~m}$ ). Trawlers were the only group to declare that the FMZ had no impact on their fishing activity.

When questioned about the effect of the FMZ in protecting biodiversity, most respondents gave either a neutral response or indicated that the FMZ does not help to protect biodiversity. Significant negative results $(P<0.05$; Table 6$)$ were obtained for full-time fish- ers, fishers from Marsaxlokk port and the masters of 12-24 m vessels. Only recreational fishers thought that the FMZ helped to protect biodiversity $(P<0.05$; Table 6$)$. Fishers with $>35$ years fishing experience thought that the FMZ did not enhance fish abundance in the area $(P<0.05$; Table 6$)$, while the rest of the groups analysed had a neutral response, on average. Most of the fishers did not think that the FMZ benefited stocks outside the area. Significant negative responses $(P<0.05$; Table 6$)$ were obtained for longliners, full-time and fishers from Marsaxlokk port and the masters of $12-24 \mathrm{~m}$ vessels. The response from the recreational fishers was not significant after the Bonferroni correction. $(P<0.05$; Table 6$)$.

Most fishers thought that the FMZ did not benefit professional fishers (MFA and MFB), with significant negative responses for longliners, full-time, fishers from Marsaxlokk port and masters of $12-24 \mathrm{~m}$ vessels $(P<0.05$; Table 6$)$. Part-time fishers, however, thought that the FMZ benefited professional fishers $(P<0.05$; Table 
Table 6

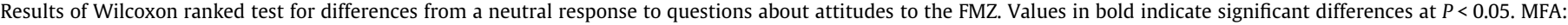
full-time; MFB: part-time; MFC: recreational; BT: exclusive bottom trawler; NT: non-exclusive netter; SN: non-exclusive seine netter; LL: non-exclusive longliner.

\begin{tabular}{|c|c|c|c|c|c|c|c|c|c|c|c|c|}
\hline \multirow{2}{*}{ Gear category } & \multicolumn{2}{|l|}{ BT } & \multicolumn{2}{|l|}{ NT } & \multicolumn{2}{|l|}{ SN } & \multicolumn{2}{|l|}{$\underline{\mathrm{LL}}$} & \multicolumn{4}{|c|}{ Questions } \\
\hline & W statistic & $P$ & W statistic & $P$ & W statistic & $P$ & W statistic & $P$ & & & & \\
\hline A & 3 & 1.00 & 0 & 0.37 & 123 & $<0.01$ & 60 & $<0.01$ & A & \multicolumn{3}{|c|}{ Impact of the FMZ on fishing activity } \\
\hline B & 3 & 1.00 & 11 & 1.00 & 231 & 0.74 & 119 & 0.06 & $\mathrm{~B}$ & \multicolumn{3}{|c|}{ FMZ helps to protect biodiversity } \\
\hline C & 8 & 0.36 & 8 & 0.18 & 602 & 0.57 & 349 & 0.14 & $\mathrm{C}$ & \multicolumn{3}{|c|}{ FMZ helps to enhance fish abundance inside area } \\
\hline $\mathrm{D}$ & 3 & 1.00 & 20 & 0.81 & 197 & 0.09 & 165 & $<0.01$ & $\mathrm{D}$ & \multicolumn{3}{|c|}{ FMZ helps to enhance fish abundance outside area } \\
\hline $\mathrm{E}$ & 3 & 0.28 & 32 & 0.31 & 402 & 0.04 & 426 & $<0.01$ & $\mathrm{E}$ & \multicolumn{3}{|c|}{ FMZ benefits mainly professional fishing } \\
\hline $\mathrm{F}$ & 9.5 & 0.69 & 36 & 0.12 & 1144 & $<0.01$ & 991 & $<0.01$ & $\mathrm{~F}$ & \multicolumn{3}{|c|}{ FMZ benefits mainly recreational fishing } \\
\hline G & 18 & 0.14 & 10.5 & 0.61 & 468 & 0.08 & 277 & 0.82 & G & \multicolumn{3}{|c|}{ FMZ reduces conflicts among users } \\
\hline $\mathrm{H}$ & 3 & 1.00 & 16 & 0.83 & 479 & 0.66 & 415 & 0.65 & $\mathrm{H}$ & \multicolumn{3}{|c|}{ FMZ reduces illegal fishing } \\
\hline I & 7.5 & 0.47 & 1 & 1.00 & 241 & 0.04 & 380 & 0.01 & I & \multicolumn{3}{|c|}{ FMZ is good for local economy } \\
\hline Licence type & \multicolumn{2}{|l|}{ MFA } & \multicolumn{2}{|l|}{ MFB } & \multicolumn{2}{|l|}{ MFC } & Base port & Gozo & \multicolumn{2}{|c|}{ Marsaxlokk } & \multicolumn{2}{|c|}{ Other } \\
\hline A & 184 & $<\mathbf{0 . 0 1}$ & 51 & 0.14 & 0 & $<0.01$ & 6 & 0.02 & 190 & $<0.01$ & 32 & $<0.01$ \\
\hline B & 55 & $<0.01$ & 545 & 0.14 & 193 & $<0.01$ & 53 & 0.09 & 168 & 0.03 & 633 & 0.11 \\
\hline C & 699 & 0.42 & 502 & 0.19 & 223 & 0.11 & 57 & 0.37 & 616 & 0.14 & 995 & 0.28 \\
\hline D & 171 & $<0.01$ & 390 & 1.00 & 246 & 0.03 & 24 & 0.45 & 364 & 0.01 & 654 & 0.35 \\
\hline E & 331 & $<0.01$ & 700 & $<0.01$ & & N.A & 67 & 0.42 & 417 & $<0.01$ & 323 & 0.67 \\
\hline $\mathrm{F}$ & 2343 & $<0.01$ & 607 & 0.66 & & N.A & 138 & 0.02 & 1456 & $<0.01$ & 564 & 0.16 \\
\hline G & 901 & 0.01 & 225 & 0.47 & 208 & 0.04 & 42 & 0.50 & 554 & 0.33 & 873 & $<0.01$ \\
\hline $\mathrm{H}$ & 755 & 0.73 & 399 & 0.52 & 175 & 0.76 & 83 & 0.21 & 676 & 0.73 & 643 & 0.29 \\
\hline I & 830 & $<0.01$ & 81 & 0.85 & 46 & 0.29 & 5 & 1.00 & 525 & $<0.01$ & 388 & $<0.01$ \\
\hline Time fishing & \multicolumn{2}{|l|}{$<15 y r s$} & \multicolumn{2}{|l|}{$15-35 y r s$} & \multicolumn{2}{|l|}{$>35 y r s$} & Vessel size & $<12 \mathrm{~m}$ & \multicolumn{2}{|c|}{$12-24 \mathrm{~m}$} & \multicolumn{2}{|c|}{$>24 \mathrm{~m}$} \\
\hline A & 17 & $<0.01$ & 240 & $<0.01$ & 173 & $<0.01$ & 175 & $<0.01$ & 31 & $<0.01$ & 4 & 0.86 \\
\hline B & 341 & 0.29 & 344 & 0.53 & 113 & 0.75 & 1503 & 0.13 & 27 & 0.03 & 3 & 1.00 \\
\hline C & 641 & 0.78 & 789 & 0.69 & 117 & 0.03 & 2112 & 0.94 & 258 & 0.16 & 5 & 0.59 \\
\hline D & 392 & 0.98 & 366 & 0.29 & 129 & 0.11 & 1614 & 0.44 & 35 & $<0.01$ & 5 & 0.59 \\
\hline $\mathrm{E}$ & 133 & 0.11 & 612 & 0.02 & 348 & 0.09 & 1130 & 0.71 & 128 & $<0.01$ & 0 & 0.10 \\
\hline $\mathrm{F}$ & 289 & 0.13 & 1514 & $<0.01$ & 114 & $<0.01$ & 1546 & 0.02 & 1041 & $<0.01$ & 5 & 0.59 \\
\hline G & 447 & 0.08 & 784 & 0.04 & 152 & 1.00 & 1391 & 0.39 & 349 & 0.02 & 15 & 0.06 \\
\hline $\mathrm{H}$ & 406 & 0.96 & 800 & 0.99 & 36 & 0.36 & 1808 & 0.77 & 254 & 0.32 & 7 & 0.89 \\
\hline I & 185 & 0.02 & 630 & $<0.01$ & 36 & 0.77 & 616 & 0.04 & 296 & $<0.01$ & 8 & 0.47 \\
\hline
\end{tabular}

6). All of the recreational fishers declined to comment whether the FMZ mainly benefited professional or recreational fishers. Most of the professional fishers considered that the FMZ mainly benefited recreational fishers $(P<0.05$; Table 6$)$.

Most fishers expressed the view that the FMZ reduced conflicts among users and that it was good for the local economy $(P<0.05$; Table 6). The fishers also stated that the FMZ had no impact on illegal fishing.

When asked about the relationship with other users, all groups answered that they had good cooperation with all users, except that professional fishers considered that there was conflict with foreign fishers when fishing outside the FMZ. For ease of interpretation, results are presented graphically only for the professional (MFA and MFB) and recreational (MFC) fishers (Fig. 3).
Fishers were asked whether the FMZ had influenced their manner of fishing and $32 \%$ of the respondents answered positively. The main changes were that they had ceased to fish in the FMZ (75\%), that they now targeted other species $(13 \%)$ or that they had purchased another vessel (4\%).

When considering the whole suite of responses together, the multivariate analysis indicated significant differences (ANOSIM $P<0.05$, Table 7 ) in the fishers' perceptions by gear and licence category, years fishing and vessel length. Positive $R$ values indicate some discrimination among the groups, whereas negative values indicate that within-group differences were greater than those among groups. In relation to gear type category, the responses of recreational fishers (MFC) differed significantly from all other groups, which were not significantly different from each other

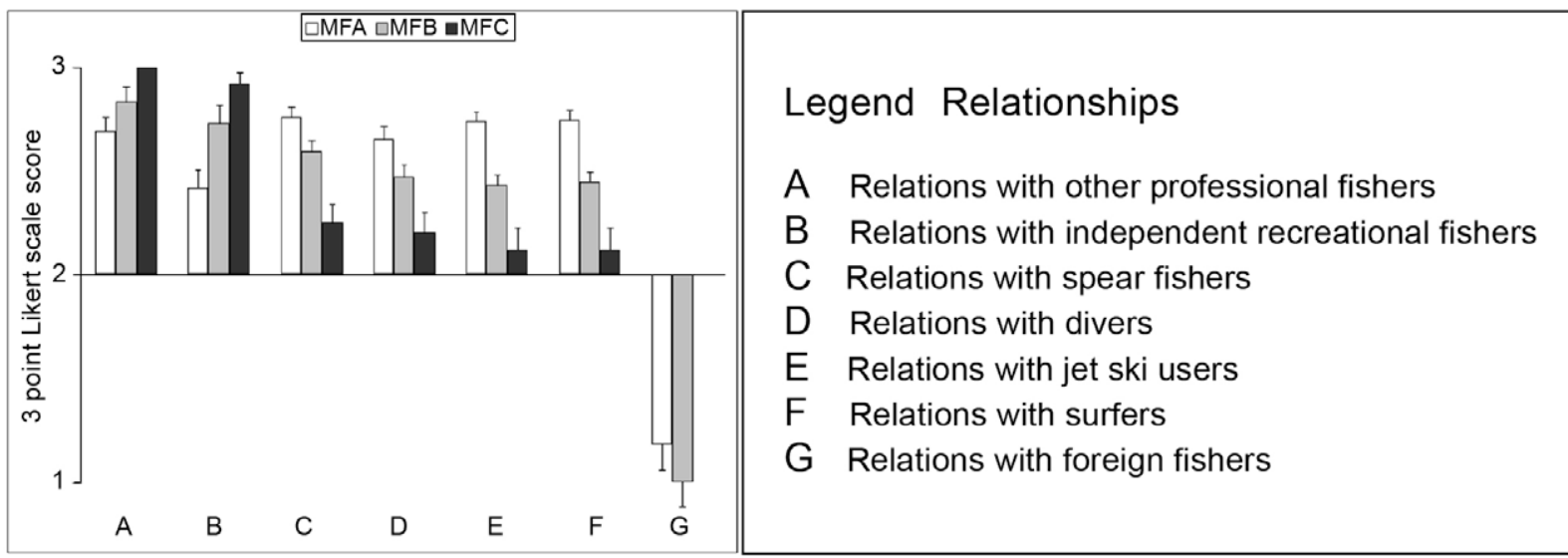

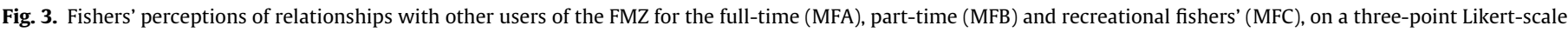
from 1 'conflict' to 3 'good cooperation'. The error bars show the standard error. The legend from A to G shows the questions asked. 
Table 7

Multivariate analysis of similarity (ANOSIM) test results for the 32 dependent variables and the respective groupings. The test statistic $\mathrm{R}$ is given for each pairwise comparison, with its associated probability, with bold figures denoting significant differences. MFA: full-time; MFB: part-time; MFC: recreational; BT: exclusive bottom trawler; NT: non-exclusive netter; SN: non-exclusive seine netter; LL: non-exclusive longliner.

\begin{tabular}{lcl}
\hline Groups & $R$ statistic & $P$ \\
\hline Gear category & 0.09 & $\mathbf{0 . 0 0 2}$ \\
SN, LL & 0.004 & 0.34 \\
SN, BT & -0.059 & 0.703 \\
SN, NT & -0.057 & 0.772 \\
SN, MFC & 0.183 & $\mathbf{0 . 0 0 1}$ \\
LL, BT & 0.002 & 0.465 \\
BT, NT & 0.028 & 0.333 \\
LL, MFC & 0.329 & $\mathbf{0 . 0 0 1}$ \\
BT,NT & -0.02 & 0.572 \\
BT, MFC & 0.456 & $\mathbf{0 . 0 0 1}$ \\
NT, MFC & 0.465 & $\mathbf{0 . 0 0 1}$ \\
Licence type & 0.131 & $\mathbf{0 . 0 0 1}$ \\
MFA, MFB & 0.074 & $\mathbf{0 . 0 0 1}$ \\
MFA, MFC & 0.188 & $\mathbf{0 . 0 0 1}$ \\
MFB, MFC & 0.229 & $\mathbf{0 . 0 0 1}$ \\
Base port & 0.004 & 0.375 \\
Marsaxlokk, Gozo & 0.033 & $\mathbf{0 . 0 0 7}$ \\
Marsaxlokk, Other & -0.145 & 0.999 \\
Gozo, Other & 0.034 & 0.236 \\
Years fishing & 0.032 & 0.028 \\
$>35$ y, 15-35 y & 0.07 & 0.029 \\
$>35$ y, <15 y & 0.105 & $\mathbf{0 . 0 0 2}$ \\
15-35 y,<15 y & -0.015 & 0.877 \\
Vessel length & 0.119 & $\mathbf{0 . 0 0 1}$ \\
12-24 m,>24 m & 0.157 & $\mathbf{0 . 0 0 1}$ \\
12-24 m, <12 m & 0.127 & $\mathbf{0 . 0 0 1}$ \\
$>24$ m,<12 m & 0.036 & $\mathbf{0 . 0 0 1}$ \\
\hline & & \\
& &
\end{tabular}

(ANOSIM $P<0.05$, Table 7 ). The analysis of classification by licence type gave the largest global R statistic (ANOSIM $P<0.05$, Table 7 ), with significant differences between all three groups (Fig. 4). The recreational fishers and full-time fishers were most different, while the part-time fishers were intermediate between these two groups. The full-time fishers appeared to exhibit the greatest variability in their responses.

Fishers who have been fishing for more than 35 years had significantly different perceptions regarding the FMZ (ANOSIM $P<0.05$, Table 7) compared with less-experienced fishers, mostly in that they expressed the view that the FMZ does not enhance fish

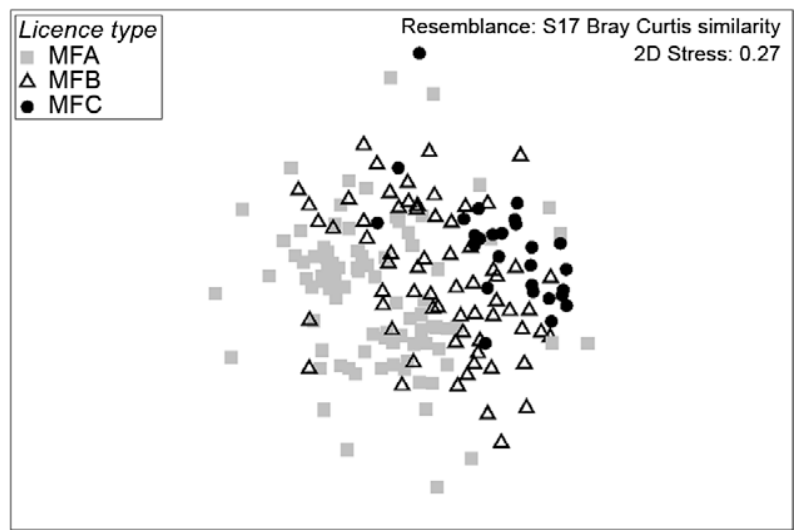

Fig. 4. Non-metric multi-dimensional scaling (nMDS) plot for the replicate questionnaires based on 32 dependent variables (responses) labelled by licence category: MFA: full-time fishers, MFB: part-time Fishers and MFC: recreational Fishers. With a stress level of 0.27 it may be that the groups would be more clearly separated in a three-dimensional plot. abundance in the area and it does not reduce illegal fishing (Fig. 2). The opinions of fishers from the main fishing village of Marsaxlokk were significantly different (ANOSIM $P<0.05$, Table 7 ) from all other fishing villages in that practically the protection and enhancing effect of the FMZ on the stocks was not happening (questions B, C, D) and it did not reduce illegal fishing, with views expressed that the FMZ did not protect or enhance fish stocks (questions B, C, D) and did not reduce illegal fishing (Fig. 2). The opinions of fishers also differed significantly in relation to size of vessel (ANOSIM $P<0.05$, Table 7 ), whereby masters of larger vessels ( $>24 \mathrm{~m}$ ) perceived that the FMZ did not enhance fish abundance.

The SIMPER analysis indicated that differences in the choice of fishing site were the most important factor contributing to the dissimilarity among groups, followed by responses to questions about the benefit of the FMZ to fisheries (Table 8).

The BIOENV analysis revealed that a combination of three demographic variables gave the best rank correlation with the responses made by fishers. The most-positive correlations were obtained by the combined variables licence category and owner of vessel (0.173); however, the correlation coefficients were all very low.

\section{Discussion}

The aim of the study was to determine the perceptions and attitudes of the resource-users that have exclusive access to the FMZ which was established primarily to conserve fish stocks for Maltese fishers. Understanding heterogeneity in fishers' attitudes towards management interventions is important to understand their impact on different stakeholder groups (Gelcich et al., 2005b). Following accession to the EU in 2004 the aim of the zone was to act as a fisheries conservation area in the Sicilian Channel. Fishers' perceptions and attitudes may change with time as new generations replace the old ones and the former become accustomed to their present situation and hence the original perception of the exclusivity of the zone may be lost. This was examined by looking at the perceptions and attitudes of fishers that fished prior to the establishment of the original 25-NM exclusive fisheries zone in 1971.

The characteristics of the fishers differed mostly between the professional and recreational fishers and to a lesser extent between the commercial full-time and part-time fishers. Full-time professional fishers expressed stronger opinions than part-timers, who were neutral on most issues. Recreational fishers were moderately opinionated too, but with different views. For the gear categories investigated, no major differences were evident, except for netters who had smaller boats and hence a low second hand value of the boat. Total costs and landings were similar throughout the professional gear classes except for bottom trawlers which had the highest annual values for landings (ca. $€ 42,000 \mathrm{y}^{-1}$ as opposed to ca. $€ 15,000 \mathrm{y}^{-1}$ for the other categories). The other commercial fleet categories had similar total value of landings (ca. $€ 15,000 \mathrm{y}^{-1}$ ) with the netters having almost three times the quantity of landings (ca. $10 \mathrm{t}$ as opposed to $3 \mathrm{t}$ ) as the seine netters and longliners, however, none of these differences were significant due to the high variability in the data. One reason for the lack of differences between the longliners and seine netters is that some fished species yield high unit values in a short period of time, such as in the longline bluefin tuna fishery and other fished species yield a relatively low unit value spread over a longer period of time, as illustrated by the dolphinfish fishery undertaken by seine netters. Bottom trawlers on the other hand exerted comparatively constant fishing effort, targeting deep water red shrimp (Aristeomorpha foliacea) throughout the year, yielding the highest value of landings.

The most important factor that determined the choice of fishing site was fishery regulations. Some fishers may have responded this 
Table 8

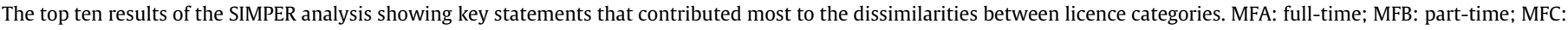
recreational; SD: Standard Deviation; Diss/SD: dissimilarity/standard deviation; Contrib\%: contribution\% to Diss/SD; Cum.\%: Cumulative\% of the\% contribution to Diss/SD.

\begin{tabular}{|c|c|c|c|c|c|c|c|}
\hline $\begin{array}{l}\text { Average dissimilarity }=24.12 \\
\text { Attitude/perception }\end{array}$ & $\begin{array}{l}\text { MFA } \\
\text { Mean response }\end{array}$ & $\begin{array}{l}\text { MFB } \\
\text { Mean response }\end{array}$ & Av.diss & SD & Diss/SD & Contrib.\% & Cum.\% \\
\hline \multicolumn{8}{|l|}{ MFA and MFB } \\
\hline Factor affecting choice of fishing site - Regulations & 2.52 & 2.24 & 2.28 & 2.02 & 1.13 & 9.45 & 9.45 \\
\hline Factor affecting choice of fishing site - Experience & 0.65 & 2.49 & 2.19 & 1.90 & 1.15 & 9.09 & 18.55 \\
\hline Factor affecting choice of fishing site - Weather & 1.98 & 1.03 & 1.89 & 1.80 & 1.05 & 7.84 & 26.39 \\
\hline FMZ benefits mainly professional fishing & 1.91 & 3.49 & 1.81 & 1.20 & 1.51 & 7.52 & 33.91 \\
\hline Factor affecting choice of fishing site - Abundance of fish & 1.37 & 1.25 & 1.69 & 1.84 & 0.92 & 7.00 & 40.91 \\
\hline FMZ benefits mainly recreational fishing & 4.00 & 3.06 & 1.51 & 1.16 & 1.30 & 6.26 & 47.17 \\
\hline FMZ helps to enhance fish abundance inside area & 3.00 & 2.82 & 1.02 & 0.82 & 1.25 & 4.22 & 51.39 \\
\hline FMZ reduces illegal fishing & 3.03 & 2.93 & 0.99 & 0.84 & 1.18 & 4.09 & 55.47 \\
\hline Influence of FMZ on the way to fish & 1.96 & 1.24 & 0.88 & 0.87 & 1.01 & 3.67 & 59.14 \\
\hline FMZ helps to protect biodiversity & 2.76 & 3.19 & 0.87 & 0.79 & 1.10 & 3.61 & 62.75 \\
\hline \multicolumn{8}{|l|}{ MFA and MFC } \\
\hline Average dissimilarity $=26.52$ & MFA & MFC & & & & & \\
\hline Factor affecting choice of fishing site - Regulations & 2.52 & 1.00 & 2.31 & 2.03 & 1.14 & 8.72 & 8.72 \\
\hline Factor affecting choice of fishing site - Abundance of fish & 1.37 & 2.15 & 2.10 & 2.00 & 1.05 & 7.91 & 16.63 \\
\hline Factor affecting choice of fishing site - Weather & 1.98 & 1.74 & 2.00 & 1.72 & 1.16 & 7.55 & 24.18 \\
\hline Factor affecting choice of fishing site - Accessibility & 0.06 & 2.22 & 1.94 & 1.94 & 1.00 & 7.32 & 31.5 \\
\hline Factor affecting choice of fishing site - Experience & 0.65 & 1.37 & 1.40 & 1.52 & 0.92 & 5.30 & 36.8 \\
\hline FMZ benefits mainly professional fishing & 1.91 & 3.00 & 1.36 & 0.79 & 1.73 & 5.13 & 41.93 \\
\hline FMZ helps to enhance fish abundance outside area & 2.67 & 3.59 & 1.31 & 0.87 & 1.51 & 4.96 & 46.89 \\
\hline FMZ benefits mainly recreational fishing & 4.00 & 3.00 & 1.23 & 0.79 & 1.56 & 4.64 & 51.53 \\
\hline FMZ helps to protect biodiversity & 2.76 & 3.70 & 1.21 & 0.88 & 1.37 & 4.55 & 56.08 \\
\hline FMZ helps to enhance fish abundance inside area & 3.00 & 3.41 & 1.20 & 0.90 & 1.34 & 4.51 & 60.59 \\
\hline \multicolumn{8}{|l|}{ MFB and MFC } \\
\hline Average dissimilarity $=23.77$ & MFB & MFC & & & & & \\
\hline Factor affecting choice of fishing site - Experience & 2.49 & 1.37 & 2.20 & 1.82 & 1.21 & 9.25 & 9.25 \\
\hline Factor affecting choice of fishing site - Regulations & 2.24 & 1.00 & 2.13 & 1.94 & 1.10 & 8.94 & 18.19 \\
\hline Factor affecting choice of fishing site - Abundance of fish & 1.25 & 2.15 & 2.04 & 1.92 & 1.06 & 8.56 & 26.75 \\
\hline Factor affecting choice of fishing site - Accessibility & 0.00 & 2.22 & 1.94 & 1.98 & 0.98 & 8.18 & 34.93 \\
\hline Factor affecting choice of fishing site - Weather & 1.03 & 1.74 & 1.70 & 1.60 & 1.06 & 7.17 & 42.09 \\
\hline FMZ helps to enhance fish abundance inside area & 2.82 & 3.41 & 1.25 & 0.97 & 1.29 & 5.25 & 47.34 \\
\hline FMZ helps to enhance fish abundance outside area & 3.00 & 3.59 & 1.16 & 0.85 & 1.36 & 4.88 & 52.22 \\
\hline FMZ helps to protect biodiversity & 3.19 & 3.70 & 1.13 & 0.90 & 1.25 & 4.77 & 56.99 \\
\hline FMZ reduces illegal fishing & 2.93 & 3.07 & 1.08 & 0.84 & 1.28 & 4.56 & 61.55 \\
\hline FMZ reduces conflicts among users & 2.93 & 3.52 & 1.08 & 0.80 & 1.35 & 4.56 & 66.1 \\
\hline
\end{tabular}

way because they thought that the questionnaire would be used for enforcement proposes. Some other responses may also have been deliberately inaccurate or withheld, if there was any irregularity in fishing activity, as certain fishing activities are restricted within the FMZ. However, most fishers were forthright (c.f. evasive) and gave the impression that they needed to talk to someone and express their feelings about the current situation of the FMZ. Nevertheless, regulations seem important for fishers and this means that regulations and their enforcement are vital for the success of fisheries management.

\subsection{Fishers' perceptions and attitudes}

In general, the perceptions of fishers were that the FMZ has had a negative impact on fishing activity. Professional fishers perceived that the FMZ does not protect fishery resources because their major income derives from highly migratory species, including dolphinfish, bluefin tuna and swordfish, which comprise more than $80 \%$ of the total annual landings (Agriculture and Fisheries, 2005). Highly migratory species are not protected by marine protected areas or fisheries restricted areas such as the FMZ, since these species are vulnerable to a multitude of fishers outside the conservation zone. The negative perceptions of the fishers surveyed about the conservation effect of the FMZ and its use in the conservation of the stocks were also apparent from comments made to interviewers while administering the interviews. The fishers' lack of ownership of the migratory resources was raised by many with comments such as 'fish are caught by big foreign boats' and 'foreign boats are ruining our gear' and this was reflected in the responses indicating that there was conflict only with foreign fishers (Fig. 3). Another reason for the negative perceptions of the fishers on the FMZ was that following the accession of Malta into the EU in 2004 a restriction was applied that vessels $>12 \mathrm{~m}$ L.O.A. could not fish within the 25-NM zone except for trawling, purse seining for small pelagic fish (lampara), and fishing for dolphinfish, tuna, swordfish and other highly migratory species. This meant that netters and bottom longliners $>12 \mathrm{~m}$ were excluded from fishing in the FMZ.

In contrast to pelagic fishers, trawlers and netters that fished for demersal species had an overall neutral response and may have either perceived some benefits of the conservation area or been accustomed to any benefits the FMZ might have since these fishers have been fishing in the FMZ for many years. Bottom trawlers and netters also seem to have the most incentive for establishing property rights, since the stocks they target are not migratory and therefore remain within the FMZ.

Older fishers claim that the FMZ did not enhance fish abundance within it. This may be due to the fact that the old fishers were accustomed to fishing in inshore and coastal waters and had to fish further away from the coast as fish stocks declined over time. Since the establishment of the exclusive fishing zone in 1971, the population of the Maltese archipelago has increased from 326,000 in 1970 to 403,500 in 2005. The number of commercial and recreational fishers has increased correspondingly. In the 1970 s through to the 1990s, there were also an increase in the number of spear fishers, which drastically reduced the number of large coastal demersal fish, such as groupers (Epinephelus spp.) and bream (Sparidae). According to the fishers that have been fish- 


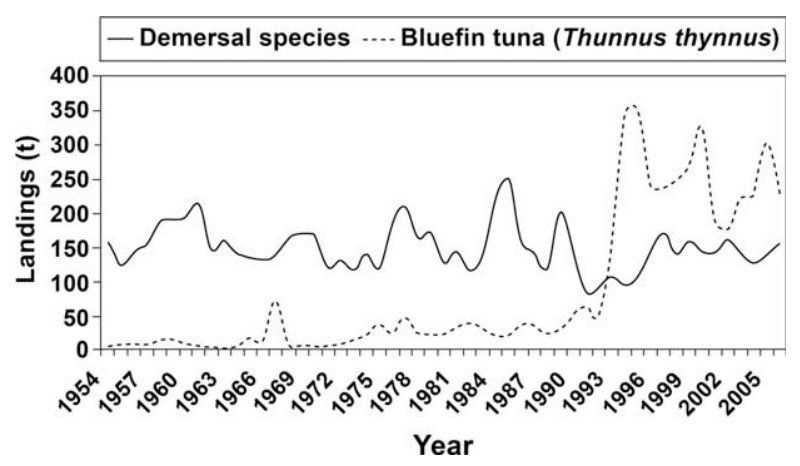

Fig. 5. Total landings $(t)$ from the Maltese Islands for bluefin tuna and demersal species from 1954 to 2006.

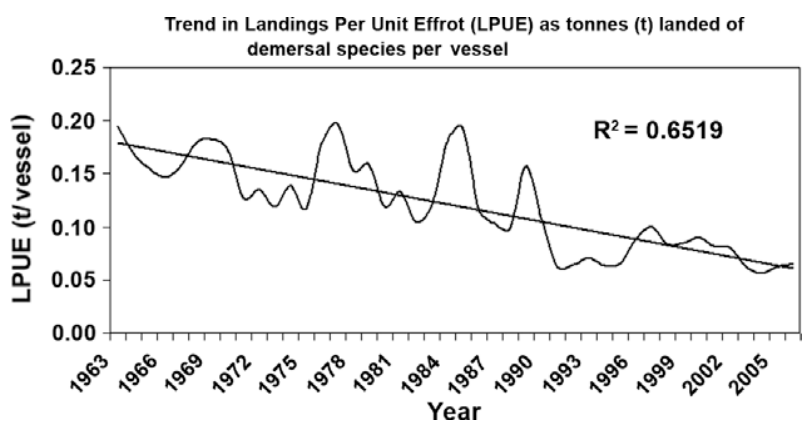

Fig. 6. Trend in Landings Per Unit Effort (LPUE) for the Maltese Islands for the demersal species from 1963 to 2006.

ing for more than 35 years, accounts of 'large fish being caught very close to the coast are a thing of the past'. The shift from fishing in inshore to off-shore waters can clearly be seen from the national total landings in Fig. 5. The total landings of demersal species decreased drastically in 1991 and landings of large pelagics, mostly bluefin tuna (Thunnus thynnus), increased sharply in 1993-1994. The landings of demersal species started to increase again in 1996 when bottom longliners started fishing off-shore as well. The landings per unit effort (LPUE) for the Maltese islands have halved since 1963 (Fig. 6). The fishery statistics tend to confirm the overall negative perception of fishers about the FMZ, which did not seem to have functioned properly as a conservation zone. The decreasing trend in LPUE is due to the continued increase in the number of vessels since 1954 and the increased fishing capacity of the vessels, with improved engines and better equipment for fishing.

Most fishers expressed the view that the FMZ reduced conflicts among users and that it was good for the local economy, however, the fishers also clearly stated that conflicts arose with foreign fishers. Accordingly, their response was most probably related to the reduction of conflicts between local fishers, who were more concerned about conflicts with foreign vessels (the 'common enemy'). Furthermore the fishers responded that the FMZ was good for the local economy but most groups interviewed claimed it had a general negative impact on fish abundance inside and outside the zone. These two statements are contradictory. One possible reason for this is that the fishers' response that the FMZ is important for the local economy may be directed towards the economy of the country but not the fishing economy $(P<0.05$; Table 6$)$. The fishers also stated that the FMZ had no impact on illegal fishing, so the control and enforcement system in place is either not having an effect on illegal fishing or is not being perceived by the fishers.

Although all the groupings investigated showed some differences in perceptions, the largest differences were those between the recreational and the professional fishers, with the former having strong beliefs that the FMZ was set up to protect marine resources inside the zone. When the whole suite of attitudes was analysed, the main differences were between the three licence categories (MFA, MFB, MFC) and fishers that have been fishing for more than 35 years and the ones which have been fishing less. Apparent differences in relation to vessel length may have been confounded with licence category.

The most evident differences were between the three licence categories, where the multivariate analysis indicated that the full-time fishers are at one extreme and recreational fishers at the other, although there was an attitudinal continuum between the three groups of fishers. According to Gelcich et al. (2005a), understanding the complexity in livelihoods of artisanal fishers is crucial to understanding the driving forces behind fishers' behaviours. The results of the present study show that the dependence on fishing for the fisher's income was the strongest factor influencing attitudinal differences. The importance of managing fishers according to their livelihood has been recognised also by other studies (Scoones, 1998; Allison and Ellis, 2001), since it may improve rural development policy and practice by recognising the seasonal complexity of livelihood strategies. In this approach, it is necessary to consider the conditions that create economic niches for coastal residents and that relate to specific lifestyles (Allison and Ellis, 2001). The 'livelihoods' approach to fisheries management also fits with the ecosystem approach (Jorgensen and Muller, 2000) were management addresses the whole marine ecosystem and extends this approach to take local socio-economic factors into account resulting in an integrated management system incorporating ecological and socio-economic aspects. In the present case study, the current vessel licensing system represents a management system based partly on the livelihood approach.

Social influences on the fishers' behaviour were reflected in the different overall attitudes of fishers from the main fishing of Marsaxlokk. Fishers from there are known in Malta to be particularly different in their attitudes from other villages. In fact, the people from this village also have their own dialect and accent. The social background of fishers from this village may have influenced their perceptions. The village has the longest history of fishing activity, with stories of fishing in past times being passed down the generations, so the particular cultural and social characteristics of this village may have accounted for the attitudinal difference of its fishers.

\subsection{Management implications}

Significant differences in resource use, world views, and attitudes exist among artisanal fishers in Malta, as in many other countries (Sandersen and Koester, 2000; Perez-Sanchez and Muir, 2003; Hampshire et al., 2004). These differences must be identified and understood if co-management and conservation are to be more inclusive and participatory and thus more effective (Sandersen and Koester, 2000; Sittert, 2003). Current management assumes that fishers will respond homogeneously and deterministically to a given management action. The results of the present study, however, suggest that the attitudes of fishers to management measures vary with their dependence on fishing for their livelihoods, origin and fishing experience. Hence, the response to management is likely to vary both among and within-groups. Understanding this variability is important for predicting the likely success of any given management measure. The behaviour of fishers towards conservation also depends on their perceptions of the management regime. If fishers are confident that the management regime is beneficial to the sustainability and conservation of fisheries resources their behaviour will be in favour of, and correspond with, regulations that directly protect the same resources. 
Although at one level, individual differences in circumstance may make different people respond differently to the same management tool, it is clearly unrealistic for policy makers to consider all individual responses separately. So to aid understanding of these differences, some sort of loose taxonomy of "response type," as determined by attitudes, objectives, and other socio-economic variables, may be helpful. Based on our current understanding of the Maltese situation, it seems that fishers could be grouped into one of three domains of attitudes: recreational, commercial fulltime and commercial part-time.

The main causes of attitudinal heterogeneity among fishers of different groups are related to their attitude toward the protection and conservation effect of the FMZ, enhancement of resources and conflicts. The differences in fishers' attitudes between the commercial and recreational fishers toward these key issues are especially important, because human behaviour is determined by specific attitudes and the beliefs that people hold (Ajzen, 1988; Beedell and Rehman, 1999). Consequently, these underlying attitudes could lead to future observable differences in management style. These attitudes influence fishers' voluntary participation in enforcing regulations (for example, by reporting illegal fishing activities) and thus affect the wider impact on marine natural resources. At the moment this is already happening in the FMZ, since local fishermen routinely report foreign fishers, especially trawlers that enter the zone to fish illegally. This attitude had been detected in the relationships analysis, where the fishers related their conflict with the foreign fishers (Fig. 3).

The suite of attitudes and perceptions studied gave slight positive correlations, with the licence category (MFA, MFB, MFC) being the most important. Nevertheless, no combination of demographic variables correlated significantly with the subset of questions, which indicated that this attitudinal domain was determined primarily by other factors, such as social norms (Aipanjiguly et al., 2003), ethical considerations, and personality, as has been found for farmers (Willock et al., 1999a,b).

The importance of individual attitudes in determining behaviour raises the possibility that although a new management action or tool may change fishers' short-term behaviour, if the management policy is not accompanied by any changes in fishers' perception and social norms, after a period of time that the management tool is implemented or in times of crisis, fishers may revert to their traditional behavioural patterns, which could compromise long-term fisheries sustainability (Pretty, 2003). Hence fishers' participation is vital in designing and implementing management measures. Furthermore, once a management policy is adopted and the appropriate management actions are taken, regular monitoring of the fishers perceptions must be implemented to determine if the new management decisions had the desired effect on fishers' attitudes. The results obtained from such monitoring could be used in adaptive management (Jacobson et al., 2003).

Communication is very important for the successful implementation of new policies and management actions, in that it can influence the attitude of stakeholders to new initiatives. All the stakeholders that are present within the FMZ are in fact the recipients of the messages concerning the area itself or the activities carried out in it. The aims of the communication activities answer, above all, to the stakeholders' need on FMZ knowledge and in particular that related to its fisheries sustainability, conservation and environmental characteristics and its knowledge with regards to the Maltese context. Fishers are more likely to comply with management measures and persuade others to do so if they have been consulted, been convinced of their need and had the opportunity to contribute to their formulation. Poor communication, on the other hand, is likely to lead to resentment of authority and resistance to new regulations.
An important question is whether long-standing attitudes can be changed given the present age-related differences in attitudes. Will the "attitude-profile" of the fisher population change over time, or are these attitudes determined by age and experience independently from the historical context? Can perception of management measures be altered favourably? Can management measures be designed for particular fisher groups to have the desired effect depending on the attitudes of the group? These are all questions that must be addressed if fisheries managers are to successfully manage the activity of fishers and similar user groups.

\section{Acknowledgements}

We thank all the interviewers who conducted the questionnaire surveys and Nicolas Roncin. This research was partly funded by research grants from the University of Malta and the Malta Centre for Fisheries Science (MCFS). The research presented in this paper was developed as a part of the research project "European Marine Protected Areas as Tools for fisheries Management and Conservation" (EMPAFISH SSP8-006539) supported by the Commission of the European Communities within the Sixth Framework Program. The views expressed in this work do not necessarily reflect those of the EC or anticipate the Commission's future policy in this area.

\section{References}

Agardy, T., Bridgewater, P., Crosby, M.P., Day, J., Dayton, P.K., Kenchinkton, R., Laffoley, D., McConney, P., Murray, P.A., Parks, J.E., Peau, L., 2003. Dangerous targets? Unresolved issues and ideological clashes around marine protected areas. Aquatic Conservation - Marine and Freshwater Ecosystems 13, 353367.

Agrawal, A., 2001. Common property institutions and sustainable governance of resources. World Development 29 (10), 1649-1672.

Agriculture and Fisheries, 2005. Valletta, Malta. National Statistics Office 2007, vol. $\mathrm{xv}, 119 \mathrm{pp}$.

Aipanjiguly, S., Jacobson, S., Flamm, R., 2003. Conserving manatees: knowledge, attitudes, and intentions of boaters in Tampa Bay, Florida. Conservation Biology 17, 1098-1105.

Ajzen, I., 1988. Attitudes, Personality, and Behaviour. Open University Press, Milton Keynes, United Kingdom.

Ajzen, I., 1991. The theory of planned behaviour. Organizational Behaviour and Human Decision Processes 50, 179-211.

Allison, E., Ellis, F., 2001. The livelihoods approach and management of small scale fisheries. Marine Policy 25, 377-388.

Austin, E.J., Deary, I.J., Willock, J., 2001. Personality and intelligence as predictors of economic behaviour in Scottish farmers. European Journal of Personality 15, S123-S137.

Beedell, J., Rehman, T., 1999. Explaining farmers' conservation behaviour: why do farmers behave the way they do? Journal of Environmental Management 57, $165-176$.

Baland, J.M., Platteau, J.P., 1996. Halting Degradation of Natural Resources: Is There a Role for Rural Communities? Clarendon Press, Oxford, United Kingdom.

Bentler, P.M., Speckart, G., 1979. Models of attitude-behaviour relations. Psychological Review 86, 452-464.

Blyth, R.E., Kaiser, M.J., Edwards-Jones, G., Hart, P.J.B., 2002. Voluntary management in an inshore fishery has conservation benefits. Environmental Conservation 29, 493-508.

Camilleri, M., 2003. Background to the establishment of the 25 mile Fisheries Conservation Zone around the Maltese islands. In: Proceedings of the APS Seminar 'Ecosystem Based Fisheries Management in the Mediterranean', APS Bank Publications, Malta, pp. 99-106.

Camilleri, M., 2005. Maltese fisheries and the sustainability of resources around the Maltese Islands. Ph.D. Thesis, University of Plymouth. pp. 204.

Clarke, K.R., Warwick, R.M., 1994. Similarity-based testing for community pattern: the two-way layout with no replication. Marine Biology 118, 167-176.

Dalton, T.R., Coats, R.M., Asrabadi, B.R., 2004. Renewable resources, property-rights regimes and endogenous growth. Ecological Economics 52 (1), 31-41.

De Alessi, M., 1998. Fishing for Solutions. Studies on the Environment No. 11. The Institute of Economic Affairs (IEA), London, United Kingdom.

Eggert, H., Ellegård, A., 2003. Fishery control and regulation compliance. A case for co-management in Swedish commercial fisheries. Marine Policy 27, 525533.

Featherstone, A.M., Goodwin, B.K., 1993. Factors influencing a farmer's decision to invest in long-term conservation improvements. Land Economics 69 (1), 67-81.

Filson, G.C., 1993. Comparative differences in Ontario farmers' environmental attitudes. Journal of Agricultural and Environmental Ethics 6 (2), 165-184. 
Fishbein, M., Ajzen, I., 1975. Belief, attitude, intention and behaviour: an introduction to theory and research. Reading, Massachusetts, USA: AddisonWesley cooperatives. Human Organization 52 (4), 356-367.

Flaaten, O., Heen, K., 2005. Fishing vessel profitability and local economic link obligations - the case of Norwegian trawlers. Marine Policy 28 (6), 451-457.

Fortmann, L., 1990. Locality and custom: non-aboriginal claims to customary usufructuary rights as a source of rural protest. Journal of Rural Studies 6 (2), 195-208.

Fortmann, L., 1995. Talking claims: discursive strategies in contesting property. World Development 23 (6), 1053-1063.

Furubotn, E.G., Pejovich, S., 1972. Property rights and economic theory - survey of recent literature. Journal of Economic Literature 10 (4), 1137-1162.

Gell, F., Roberts, C., 2003. Benefits beyond boundaries: the fishery effects of marine reserves. Trends in Ecology and Evolution 18, 448-455.

Gelcich, S., Edwards-Jones, G., Kaiser, M.J., 2005a. Importance of attitudinal differences among artisanal fishers with respect to co-management and conservation of marine resources. Conservation Biology 19 (3), 865-875.

Gelcich, S., Edwards-Jones, G., Kaiser, M.J., Watson, E., 2005b. Using discourses for policy evaluation: the case of marine common property rights in Chile. Society and Natural Resources 18, 1-15.

Gelcich, S., Edwards-Jones, G., Kaiser, M.J., Castilla, J.C., 2006. Co-management policy can reduce resilience in traditionally managed ecosystems. Ecosystems 9, 951-966.

Giudicelli, M., 1978. Malta. Simulated commercial trawling and scouting operations in the Central Mediterranean (January 1976-June 1977). FAO, FI: MAT/75/001/ $1,93 \mathrm{p}$.

Gordon, H.S., 1954. The economic theory of a common-property resource. the fishery. The Journal of Political Economy 62 (2), 124-142.

Hampshire, K., Bell, S., Wallace, G., Stepukonis, F., 2004. "Real" poachers and predators: shades of meaning in local understandings of threats to fisheries. Society and Natural Resources 17, 305-318.

Hanna, S.S., 2001. Managing the human-ecological interface. Marine resources as example and laboratory. Ecosystems 4 (8), 736-741.

Hanna, S.S., Smith, C.L., 1993. Attitudes of trawl vessel captains about work, resource use and fishery management. North American Journal of Fisheries Management 13, 367-375.

Hannesson, R., 2004. The Privatization of the Oceans. The MIT press, Cambridge, Mass.

Hardin, G., 1968. The tragedy of the commons. Science 162, 1228-1243.

Hart, P.J.B., 1998. Enlarging the shadow of the future: avoiding conflict and conserving fish. In: Pitcher, T.J., Hart, P.J.B., Pauly, D. (Eds.), Reinventing Fisheries Management. Kluwer Academic Publishers, London, UK, pp. 227-238.

Hatcher, A., Jaffry, S., Thébaud, O., Bennett, E., 2000. Normative and social influences affecting compliance with fishery regulations. Land Economics 76 (3), 448-461.

Hilborn, R., 1985. Fleet dynamics and individual variation: why some people catch more fish than others. Canadian Journal of Fisheries and Aquatic Science 42, 2 13.

Jacobson, S.K., Sieving, K.E., Jones, G.A., van Doorn, A., 2003. Assessment of farmer attitudes and behavioural intentions toward bird conservation on organic and conventional Florida farms. Conservation Biology 17 (2), 595-606.

Janmaat, J.A., 2005. Sharing clams: tragedy of an incomplete commons. Journal of Environmental Economics and Management 49, 26-51.

Jentoft, S., McCay, B., 1995. User participation in fisheries management. Lessons drawn from international experiences. Marine Policy 19, 227-246.

Jentoft, S., McCay, B., Wilson, D., 1998. Social theory and fisheries comanagement. Marine Policy 22, 423-436.

Jentoft, S., Davis, A., 1993. Self and sacrifice. an investigation of small boat fisher individualism and its implication for producer cooperatives. Human Organization 52 (4), 356-367.

Jones, K.L., Poole, G.C., Meyer, J.L., Bumback, W., Kramer, E.A., 2006. Quantifying expected ecological responses to natural resource legislation: a case study of riparian buffers, aquatic habitat, and trout populations. Ecology and Society 11 (2), 14.

Jorgensen, S., Muller, F., 2000. Ecosystems as complex systems. In: Jorgensen, S., Muller, F.D. (Eds.), Handbook of Ecosystem Theories and Management. CRC Press, Boca Raton, Florida, pp. 2-16.
Kaiser, M.J., 2005. Are marine protected areas a red herring or fisheries panacea? Canadian Journal of Fisheries and Aquatic Science 62, 1194-1199.

Kaplan, I.M., 1998. Regulation and compliance in the New England conch fishery: a case for co-management. Marine Policy 22 (4-5), 327-335.

Lazarus, R.S., Folkman, S., 1984. Stress, Appraisal and Coping. Springer Publications New York, USA.

Leiva, I., Busuttil, C., Darmanin, M., Camilleri, M., 1998. Project FAO COPEMED Artisanal fisheries in the western Mediterranean: Malta fisheries. The Department of Fisheries and Aquaculture. Malta unpublished report, $21 \mathrm{p}$.

Pauly, D., Christensen, V., Guenette, S., Pitcher, T., Sumaila, U., Walters, J., Watson, R. Zeller, D., 2002. Towards sustainability in world fisheries. Nature 418, 689-695.

McHenry, H., 1996. Farming and environmental discourses: a study of the deception of environmental issues in a German farming newspaper. Journal of Rural Studies 12 (4), 375-386.

McManus, J.W., 1996. Social and economic aspects of reef fisheries and their management. In: Polunin, N.V.C., Roberts, C.M. (Eds.), Reef Fisheries. Chapman and Hall, London, United Kingdom, pp. 249-281.

Moore, D., 1994. Contesting terrain in Zimbabwe eastern highlands: political ecology and peasant resource struggles. Economic Geography 69 (4), 380-401.

Myers, R., Worm, B., 2003. Rapid worldwide depletion of predatory fish communities. Nature 423, 280-283.

Ostrom, E., 1990. Governing the Commons: the Evolution of Institutions for Collective Action. Cambridge University Press, Cambridge, United Kingdom.

Perez-Sanchez, E., Muir, J., 2003. Fishermen perception on resource management and aquaculture development in Mecoacan estuary, Tabasco, Mexico. Ocean and Coastal Management 46, 681-700.

Pretty, J., 2003. Social capital and the collective management of resources. Science 302, 1912-1914.

Richardson, E.A., Kaiser, M.J., Edward-Jones, G., 2005. Variation in fishers' attitudes within an inshore fishery: implications for management. Environmental Conservation 32 (3), 213-225.

Redford, K.H., Robinson, J.G., 1987. The game of choice. Patterns of Indian and colonist hunting in the neotropics. American Anthropologist 89, 650-667.

Runolfsson, B., 1997. Fencing the oceans. A rights-based approach to privatising. Regulation 20 (3).

Sandersen, H., Koester, S., 2000. Comanagement of tropical coastal zones: the case of the Soufriere marine management area, St. Lucia, WI. Coastal Management 28, 87-97.

Scoones, I., 1998. Sustainable Rural Livelihoods: a Framework for Analysis. Working paper 72. Institute of Development Studies. University of Sussex, Brighton, United Kingdom.

Sittert, L., 2003. The tyranny of the past: why local histories matter in South African fisheries. Ocean and Coastal Management 46, 199-219.

Stelzenmüller, V., Maynou, F., Cadiou, G., Camilleri, M., Crech'riou, R., Criquet, G. Dimech, M., Le Direach, L., Esparza, O., Lenfant, P., Pérez-Ruzafa, A., Serrão Santos, R., 2008. Spatial assessment of fishing effort around European marine reserves: implications for a successful fisheries management. Marine Pollution Bulletin 56 (12), 2018-2026.

Traoré, N., Landry, R., Amara, N., 1998. On-farm adoption of conservation practices: the role of farm and farmer characteristics, perceptions and health hazards. Land Economics 74 (1), 114-127.

Wade, R., 1988. Village Republics: Economic Conditions for Collective Action in South India. ICS Press, Oakland, USA.

Willock, J., Deary, I.J., Edwards-Jones, G., Gibson, G.J., McGregor, M.J., Sutherland, A Dent, J.B., Morgan, O., Grieve, R., 1999a. The role of attitudes and objectives in farmer decision making: business and environmentally-oriented behaviour in Scotland. Journal of Agricultural Economics 50 (2), 286-303.

Willock, J., Deary, I.J., McGregor, M.M., Sutherland, A., Edward-Jones, G., Morgan, O. Dent, B., Grieve, R., Gibson, G., Austin, E., 1999b. Farmers' attitudes, objectives, behaviours and personality traits. The Edinburgh study of decision making on farms. Journal of Vocational Behaviour 54, 5-36.

Zanetell, B., Knuth, B., 2004. Participation rhetoric or community based management reality? Influences on willingness to participate in a Venezuelan freshwater fishery. World Development 32, 793-807. 